\title{
A crise e suas fronteiras: oito meses de "mensalão" nos editoriais dos jornais
}

\author{
Luis Felipe Miguel \\ Instituto de Ciência Política da Universidade de Brasília \\ Aline de Almeida Coutinho \\ Mestranda em Ciência Política da Universidade de Brasília
}

\begin{abstract}
Resumo
Com certa freqüência, a imprensa é acusada de "incendiária", alimentando as crises políticas, de forma irresponsável, na busca por melhores manchetes. A partir da análise de editoriais dos três principais jornais da imprensa brasileira entre maio e dezembro de 2005, meses do escândalo do "mensalão", este artigo observa outra faceta: como a crise é constituída como "desvio" a ser corrigido pela punição ou exclusão de determinados atores e comportamentos, impedindo que se coloque em questão os fundamentos do regime político.
\end{abstract}

Palavras-chave: mídia e política, crise política, política brasileira, Partido dos Trabalhadores, corrupção

\begin{abstract}
Press is frequently accused of being "incendiary", nourishing political crisis in an irresponsible way, in search of better headlines. This article relies on an analysis of editorial stuff of the three leading Brazilian newspapers to observe another facet: how the crisis is constituted as a "deviation" something to be corrected by punishment or exclusion of certain actors and kinds of behavior. Thus, the foundations of the political system are never put in question.
\end{abstract}

Keywords: media and politics, political crisis, brazilian politics, Workers' Party, corruption 
A crise do chamado "mensalão" - pretenso esquema de propinas pagas regularmente a parlamentares federais, com dinheiro público desviado, para que votassem a favor do governo - foi, provavelmente, a mais estrondosa da história da República ${ }^{1}$. Escândalos políticos e denúncias de corrupção de pessoas públicas são muito freqüentes no Brasil. Se a ditadura militar, graças à censura, conseguia conter a divulgação dos malfeitos de seus pró-homens, desde a redemocratização, em 1985, são tantos os casos de desvio de verbas que é difícil recordar, mesmo que sejam apenas os mais importantes.

Vários fatores contribuíram para singularizar o mensalão em meio a tantas outras derrapadas éticas da elite política nacional, entre eles o talento histriônico do principal denunciante, o deputado Roberto Jefferson, ou o fato de que eram atingidas figuras centrais do governo de um partido, o Partido dos Trabalhadores (PT), que fizera da moralização da política sua bandeira mais vistosa. Mais importante, talvez, foi a incapacidade do governo em sufocar a crise. Enquanto seu antecessor, Fernando Henrique Cardoso, impedia a abertura de Comissões Parlamentares de Inquérito, o presidente Luiz Inácio Lula da Silva, com uma base mais frágil no Congresso se viu obrigado a conviver com diferentes CPI's investigando seu governo durante meses.

Entre os fatores que explicam a importância adquirida pela crise está a ação dos meios de comunicação de massa. A revista Veja iniciou a denúncia de um esquema de corrupção nos Correios, empresa pública gerida por um dos partidos da base de sustentação do governo. O caso ganhou nova dimensão após a entrevista bombástica do então deputado Roberto Jefferson ao jornal Folha de $S$. Paulo, em 6 de junho de 2005. Nela, Jefferson afirmou que o governo pagava mesadas para deputados votarem a seu favor e cunhou o termo "mensalão". Daí em diante, os principais jornais diários e as revistas semanais de informação passaram a competir por novas denúncias e evidências contra autoridades da República, repetindo a "dobradinha" mídia/CPI que, em 1992, levou ao impeachment do presidente Fernando Collor de Melo.

Com freqüência, o comportamento da imprensa em episódios deste tipo (e no caso do "mensalão" em particular) é lido como "incendiário". A imprensa alimentaria as crises políticas, de maneira irresponsável, na busca desenfreada por melhores manchetes. Encontram-se aí ecos da crítica ao "denuncismo", a veiculação de denúncias sem a necessária averiguação, que faz da mídia um espaço

\footnotetext{
1 Uma versão anterior deste texto foi apresentada no III Congresso da Associação Latino-Americana de Ciência Política (ALACIP), realizado em Campinas (SP), em setembro de 2006. Os autores agradecem aos participantes da mesa "Meios de comunicação de massa e crise política", em especial Alessandra Aldé, Fernando Azevedo, Flávia Biroli, Milena Weber e Vera Chaia, bem como a Luiz Augusto de Souza Carneiro de Campos, Paola Novaes Ramos e Regina Dalcastagnè, pelas críticas e sugestões.
} 
MIGUEL, L. F.; COUTINHO, A.A. A crise e suas fronteiras: oito meses de "mensalão"...

de linchamento moral permanente e um instrumento nas mãos dos interesses em conflito na política (ABREU e LATTMAN-WELTMAN, 2001; LATTMAN-WELTMAN, 2002), e também da crítica ao "cinismo" dominante na cobertura política (CAPPELLA e JAMIESON, 1997). E esta foi a tônica do discurso de defensores do governo, entre os quais se destacou o cientista político Wanderley Guilherme dos Santos, que, em artigo publicado em 23 de junho de 2005 no jornal Valor Econômico, culpou a mídia pela eclosão da maior parte das crises políticas da nossa história ${ }^{2}$.

A partir da análise de órgãos da imprensa brasileira ao longo da crise de 2005, este trabalho busca observar outra faceta: como a crise é constituída enquanto "desvio" a ser corrigido pela punição ou exclusão de determinados atores e comportamentos, impedindo que se coloque em questão os fundamentos do regime político. Se o governo, os parlamentares envolvidos, o Partido dos Trabalhadores ou outros partidos políticos são apresentados como culpados, não se discute os problemas vinculados à delegação de poder por meio do voto (a abdicação compulsória do exercício da soberania por parte de seu detentor nominal, o povo) e à combinação entre a democracia concorrencial e a economia capitalista. Assim, a mídia pode ser "incendiária" na conjuntura, mas a perspectiva que apresenta desinfla os elementos potencialmente mais explosivos da crise enquanto possibilidade de contestação ao sistema.

Esta pesquisa envolveu a análise dos editoriais dos três principais jornais diários do país, durante um período de oito meses. Muitas vezes, escolher os editoriais como objeto de análise é uma necessidade de economia de recursos, já que o material noticioso tende a ser demasiado abundante. Mas pode ser um atalho perigoso, caso se verifique, como às vezes ocorre, uma postulação implícita de que o noticiário reflete automaticamente as posições apresentadas como oficiais do veículo. Esta postulação precisa ser demonstrada para cada caso - e este artigo não se propõe a buscar tal demonstração. Os dados aqui apresentados dizem respeito apenas aos editoriais, revelando como uma parcela influente da elite empresarial brasileira (os controladores da imprensa) pensou a crise política.

Na primeira seção do texto, é apresentado um breve perfil do Partido dos Trabalhadores e seu envolvimento no escândalo que suscitou a crise. Na segunda seção, são apresentados os procedimentos metodológicos da pesquisa, seguidos, na terceira seção, pela exposição dos dados. A conclusão sustenta a percepção de que, no enquadramento que seus editoriais deram à crise, os jornais a caracterizaram como o desvio de uma ordem política que, em sua essência, é a adequada e a possível.

\footnotetext{
${ }^{2}$ Na mesma linha, ver Lima (2006); ou, ainda, a reportagem de Marini (2007).
} 


\section{O PT e a crise}

Fundado no bojo da reforma partidária de 1979, no momento de liberalização da ditadura militar, o Partido dos Trabalhadores representou uma experiência inédita na vida política brasileira. Congregando um conjunto heterogêneo de aderentes, entre os quais sobreviventes da esquerda armada e militantes do catolicismo "progressista", o novo partido tinha como principal base o novo sindicalismo urbano, em especial na região industrial do $A B C$ paulista, de onde provinham suas lideranças mais importantes. Entre elas, sobressaía Luiz Inácio Lula da Silva, presidente do Sindicato dos Metalúrgicos de São Bernardo, que ganhara projeção nacional ao comandar as greves operárias de 1977 e 1978.

Singularizavam o PT, no cenário político brasileiro, tanto o fato de ser um partido que nascia "de baixo para cima" quanto sua relação com os movimentos sociais que deseja representar - uma relação em que o partido estaria a serviço destes movimentos, aprendendo com eles, em vez de deles se servir para impor um programa "pronto", como no modelo da esquerda mais tradicional. Sem nunca ter apresentado uma posição monolítica, antes pelo contrário, os petistas ganhavam uma identidade pela radicalidade com que anunciavam a idéia de que era possível fazer política de um modo diferente.

A partir daí, a história do partido pode ser contada como uma progressão quase linear, ainda que com ritmo diferenciado ao longo do tempo, na direção de maior pragmatismo e maior integração ao jogo político tradicional. Do ponto de vista interno, isto significou um crescente predomínio das tendências "moderadas" na direção partidária e o abrandamento do programa do partido (RIBEIRO, 2003). Diante do público, ocorrem mudanças na construção da imagem pública do partido e de Lula (RUBIM, 2003), nos padrões de coligação (MACHADO, 2007) e nas estratégias discursivas (MIGUEL, 2006). Interpretadas como "amadurecimento" ou "capitulação", conforme a perspectiva do observador, tais mudanças contribuíram para consolidar o PT, a partir dos anos 1990, como um dos protagonistas do jogo político brasileiro.

Boa parte do impulso para a transformação adveio do sucesso eleitoral, que impôs sua pedagogia aos petistas. É difícil manter uma posição "Ieninista" participar das eleições apenas para marcar posição e fazer proselitismo - no momento em que a vitória parece estar ao alcance da mão, ao custo de umas poucas concessões. Da mesma forma, a participação no parlamento e a administração de governos locais fornecem fortes incentivos ao pragmatismo, condição para oferecer aos eleitores algo mais do que palavras (seja na forma de leis, de políticas públicas, de serviços ou de obras).

De maneira sumária, é possível dizer que, de sua fundação até a vitória eleitoral para a presidência em 2002, o PT passou de uma situação em que se 
MIGUEL, L. F.; COUTINHO, A.A. A crise e suas fronteiras: oito meses de "mensalão"...

projetava como singular no cenário político por seu caráter classista para outra em que o diferencial buscado era ético. É a passagem do "Trabalhador vota em trabalhador", slogan da primeira experiência eleitoral do partido, em 1982, para o "Quero um Brasil decente", que a campanha de Lula anunciava 20 anos depois. A aposta na ética foi o que permitiu ao PT migrar de um discurso classista para um outro, de apelo universalista, enfrentando um dilema - manter-se fiel à base social original ou diluí-la para ampliá-la - que é recorrente nos partidos operários (PRZEWORSKI, 1985).

Por isso, os deslizes éticos do governo Lula tiveram mais impacto do que se o governo federal estivesse nas mãos de outro partido. Ainda que antes das eleições houvesse surgido denúncias envolvendo municipalidades administradas pelo PT incluindo, ao menos, um escândalo de grandes proporções, o assassinato do prefeito de Santo André, Celso Daniel, no início de 2002 - e uma crise ética e política irrompesse no governo federal já em 2004, quando se tornou pública a ligação do subchefe de assuntos parlamentares da presidência da República, Waldomiro Diniz, com o jogo do bicho carioca, foi o "mensalão" que apareceu, diante da opinião pública, como a demonstração de que o diferencial petista era apenas fachada.

Embora o neologismo "mensalão" só tenha chegado à imprensa em 6 de junho de 2005, na entrevista que o então deputado Roberto Jefferson, presidente do Partido Trabalhista Brasileiro (PTB), concedeu ao jornal Folha de S. Paulo, o ponto inicial da crise data de maio de 2005. A revista Veja divulgou uma fita de vídeo em que Maurício Marinho, um funcionário dos Correios, negociava o pagamento de propina com empresários interessados em participar de uma licitação. A partir daí, sucederam-se revelações de um grande esquema que envolveria o financiamento ilegal de campanhas eleitorais (o chamado "caixa dois", o repasse de dinheiro a partidos em troca de apoio a candidatos, o desvio de verbas de empresas públicas e a compra do voto de parlamentares em troca de um pagamento mensal (o "mensalão" propriamente dito). Duas Comissões Parlamentares Mistas de Inquérito (CPI's formadas por integrantes da câmara dos deputados e do senado federal) são instaladas, a dos Correios, em 9 de junho de 2005, e a da compra de votos, em 20 de julho de 2005. Sem que tenha alcançado um ponto final, a crise arrefeceu no segundo semestre de 2006, com o encerramento dos trabalhos das CPI's e a absorção das atenções pela campanha eleitoral. 


\section{Orientações metodológicas}

A pesquisa visou entender como a crise do "mensalão" apareceu nos editoriais de três jornais diários - Folha de S. Paulo, O Estado de S. Paulo e O Globo. Entre os "quality papers" brasileiros (isto é, excluídos os jornais de cunho popularesco), são aqueles que possuem maior circulação e alcance nacional. Foram lidos, fichados e tabulados todos os editoriais publicados entre $1^{\circ}$ de maio (mês em que eclodiu a crise) e 31 de dezembro de 2005, num total de 245 dias e 1803 editoriais, dos quais 472 se referiram, de maneira menos ou mais central, à crise política.

Como primeiro passo, os editoriais foram enquadrados de acordo com a temática dominante, de acordo com uma listagem de 20 categorias. A exceção foi a primeira categoria, exatamente "crise política", que incorporou todos os textos que tratavam do tema, ainda que lateralmente.

As categorias foram adaptadas de outra pesquisa ${ }^{3}$, após análise de amostra do corpus, chegando-se à seguinte listagem: (1) crise política, incluindo todos os editoriais que comentaram a crise do "mensalão", expondo alguma análise sobre suas causas, efeitos, personagens envolvidas, possíveis soluções etc.; (2) outros escândalos; (3) ações do poder executivo, seja da União ou dos estados; (4) propostas legislativas e ações no parlamento; (5) discussão de leis e institutos legais; (6) justiça e poder judiciário; (7) eleições de 2006; (8) ações de movimentos sociais e sociedade civil; (9) economia brasileira; (10) cidades, englobando questões como trânsito, transporte coletivo, direito do consumidor, greves em serviços públicos (exceto educação e saúde, que recebem categorias à parte), limpeza urbana, revitalização de áreas urbanas e outras; (11) criminalidade e segurança pública; (12) educação; (13) saúde; (14) meio-ambiente; (15) energia; (16) ciência e tecnologia; (17) dados demográficos e indicadores sociais; (18) internacional, incluindo política mundial (salvo quando o foco era a diplomacia brasileira), política interna de outros países e economia global; (19) relações exteriores do Brasil; e (20) outros.

Em seguida, isolados os editoriais que tratavam da crise, foram observadas as personagens vinculadas a ela, tanto indivíduos (Lula, Roberto Jefferson, José Dirceu) quanto instituições (o governo federal, o PT). Por fim, foram identificados os enquadramentos dados à crise, divididos em dois aspectos - as causas da crise, segundo os editoriais, e os remédios propostos para debelá-la.

\footnotetext{
3 Pesquisa "Determinantes de gênero, visibilidade midiática e carreira política no Brasil", apoiada pelo CNPq com dotações dos editais 45/2005 e 61/2005 e coordenada por Luis Felipe Miguel.
} 
MIGUEL, L. F.; COUTINHO, A.A. A crise e suas fronteiras: oito meses de "mensalão"...

As causas da crise foram agrupadas em 14 categorias:

(1) Corrupção do PT e/ou de seus líderes. Afirmou-se freqüentemente que a crise foi fruto de atos de corrupção do PT ou de seus membros mais célebres; nos editoriais, apareciam expressões como "macieira podre do PT"4 ou "propinoduto do PT"5 e idéias como a de que, para o partido, os fins justificam os meios 6 . Enunciados como esses se combinam, muitas vezes, com a percepção de que a irrupção da crise seria mera questão de tempo, devido à própria "natureza vil" do partido, descendente de doutrinas esquerdistas ultrapassadas e até totalitárias.

(2) Corrupção da administração petista, categoria em que os ilícitos são considerados comuns ao PT e a seus parceiros no governo federal, em especial aqueles partidos considerados nanicos e fisiológicos, como o PTB, o PL e o PP. É a noção de que a crise está vinculada à "distribuição de dinheiro ilegal entre partidos e políticos pelo propinoduto do PT"7 ou à corrupção destinada "a irrigar partidos

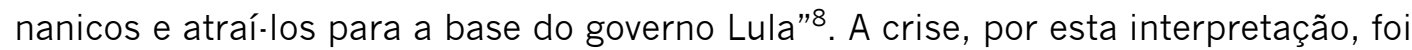
causada por atos ilegais do governo federal, não exclusivamente do partido que o comandava.

(3) Denúncias de corrupção inespecíficas. Esta terceira categoria passa a idéia de que foram atos corruptos as causas da crise, mas não explicita quem foram seus atores. Expressões como "crise da corrupção"9 exemplificam essa "despersonalização" dos atos ilícitos. Entretanto, a falta de preocupação em denunciar além da mera ocorrência da crise não impede que se perceba a quem o texto se referia, pois os agentes já tinham se tornado óbvios ao público.

(4) Fisiologismo, categoria que, embora correlata, diferencia-se da corrupção. O fisiologismo se evidencia por uma volição, um desejo de poder, vantagens e ganhos, sem o necessário desrespeito a regras. Já a corrupção, no dizer de John B. Thompson, "envolve dois elementos-chave: 1) a violação de regras, convenções ou leis referentes ao exercício adequado das obrigações públicas para fins particulares, pecuniárias ou de proveito pessoal; e 2) a perversão, ou subversão, de padrões de integridade associados a uma função pública"

\footnotetext{
4 "Ética bolchevista". OESP, 20/7/2005

5 "Verdade dos fatos". OG, 5/10/2005

6 "O fim do drama de Dirceu". OESP, 2/12/2005

7 "Biografia em jogo". OG, 9/10/2005

8 "Defesa frágil". OG, 21/10/2005

9 "A única política de Lula". OESP, 23/11/2005
} 
(THOMPSON, 2002, p. 56). Em outras palavras, quando o editorial afirma que o motivo da crise se deu por fisiologismo, há implicitamente uma condenação moral "um processo mais amplo de moralização", segundo Thompson (2002, p. 43): a busca pelo poder é censurada, embora não se afirme que esta conduta se constitua em fato antijurídico. Trata-se, antes, de uma frustração de preceitos éticos e expectativas sociais: "o presidente [...] apostou em representantes desse consórcio fisiológico de tendências políticas, dando à sua administração um perfil que já em nada representa as aspirações do eleitor por mudanças no país" ${ }^{10}$.

(5) Inexperiência de Lula e/ou do PT para governar, em que a ênfase está na desqualificação do presidente ou de seu partido:

Ao que se saiba, o presidente Lula não fez psicanálise nem antes nem depois de ascender ao Planalto. Tivesse feito, o terapeuta decerto teria oportunidades de sobra para levar o paciente a perceber a sua propensão para uma operação mental que não chega a ser propriamente rara, mas quando repetida em excesso sugere que a pessoa padece da neurose de escassez de autocrítica e de percepção enviesada da realidade que o cerca. A operação consiste em atribuir aos outros atos condenáveis de autoria própria. No caso de Lula, ou disso se trata ou é caso de má-fé política ${ }^{11}$.

Outras vezes, os editoriais reiteravam a idéia de que Lula não compreende a realidade político-social de seu país, reflexo não da falta de inteligência, mas de seu uso voltado para um projeto fisiológico de manutenção de poder.

À parte a noção tosca da inteligência como um atributo estático, que não se desenvolve com a massa de conhecimentos adquiridos ao longo da vida, a apologia da indigência cultural apenas confirma uma suspeita que não cessa de crescer à medida que Lula vai exercendo o seu mandato: a de que, tendo percorrido e tornado a percorrer os quatro cantos do País, do que tanto se orgulha, da missa não entendeu a metade. Lula jamais captou a complexidade da vida nacional, os diferentes tempos históricos que nela coexistem, as relações entre o Estado, a política e os inumeráveis interesses em movimento na órbita do poder. Daí, afinal, o seu estado de alienação, perceptível a olho nu, diante das revelações dos grossos delitos que se propagam, como uma metástase, pelo organismo da administração federal. Alienação que nos sugere a imagem de Nero tocando sua lira diante de Roma incendiada.

\footnotetext{
10 "Mágicas e conchavos". FSP, 10/7/2005

11 "Ou neurose ou má-fé". OESP, 20/12/2005.
} 
MIGUEL, L. F.; COUTINHO, A.A. A crise e suas fronteiras: oito meses de "mensalão"...

O que não significa, obviamente, que Lula seja desprovido de inteligência. 0 problema é que ela está voltada como que em tempo integral para o seu projeto personalista. $O$ presidente pode não querer saber ou não conseguir saber do que vinha se passando nos promíscuos porões onde ambições de poder guiadas pela 'ética bolchevista' se encontram com negócios movidos por uma ganância insaciável, uma coisa e outra expressas em cifras de assombrar até os brasileiros mais abonados. Mas Lula sabe perfeitamente o que quer: ficar no Planalto até 2010, com o PT ou sem, com o que há de mais execrável na política, se necessário. É para isso que "estamos dispostos a enfrentar o que é necessário". Mais difícil de explicar é o desconhecimento do País revelado pelos companheiros com "quantidade de escolaridade" maior do que ele, responsáveis pelas enormidades que passaram a vir à tona nos últimos dias ${ }^{12}$.

O governo petista, ao tentar contornar alguns efeitos da crise acaba por agravá-la, pois peca na arte da articulação ${ }^{13}$, figurando seu líder "entre os mais desastrados governantes brasileiros de todos os tempos"14, devido à "precariedade da sua visão de governança e a sua notória inapetência para as servidões da política"15. Por fim, a inexperiência de Lula e seus companheiros não se limita ao campo político, mas compromete toda ação governamental: "o Partido dos Trabalhadores não apenas chegou ao Planalto sem um plano de governo como Ihe faltava a aptidão para gerenciar programas que já existiam"16.

(6) Aparelhamento da máquina pública ou do Estado. Esta categoria abarca aquelas análises que consideram o preenchimento de cargos públicos por profissionais não especializados (pessoas geralmente ligadas a um partido político, no caso o PT) uma das causas latentes da continuidade e até de aumento da corrupção, motivo imediato da irrupção da crise política:

Em resumo, o que fizeram os Dirceus, Delúbios e sua ampla gama de sócios foi profissionalizar a corrupção - desprofissionalizando, ao mesmo tempo, a administração - numa estratégia cuidadosamente pensada para estender ao âmbito federal, com os necessários aperfeiçoamentos, o que havia sido posto em marcha em mais de uma importante prefeitura acaparada pelo PT - a começar pela de Santo André ${ }^{17}$.

\footnotetext{
12 "Em estado de alienação". OESP, 17/7/2005

13 "Desastre político". FSP, 29/6/2005

14 "Crônica de um desastre". OESP, 29/6/2005

15 "Uma incerteza a menos". OESP, 14/7/2005

16 "Adeus às ilusões". FSP, 12/6/2005

17 “Corrupção generalizada”. OESP, 7/6/2005.
} 
(7) Severino Cavalcanti e o "mensalinho". O deputado Severino Cavalcanti elegeu-se presidente da câmara dos deputados em fevereiro de 2005, em episódio que demonstrou a desarticulação política da administração petista (foi o único caso na história da República em que um candidato governista não logrou o posto) e sinalizou o descrédito do poder legislativo, pois se tratava de parlamentar julgado inexpressivo, despreparado e fisiológico. Esta categoria abriga os editoriais que comentam ou o enfraquecimento do governo federal na câmara ou o caso do chamado "mensalinho", escândalo menor em que Severino Cavalcanti foi acusado de receber propinas e que o levou a renunciar ao mandato no dia 21 de setembro de 2005.

(8) Corrupção no Legislativo, quando congressistas foram vistos como agentes nos atos de corrupção e fisiologismo que levaram à crise:

Seria um grave equívoco atribuir apenas ao Legislativo a origem dos problemas que têm desgastado a imagem da classe política e indignado o país. O Executivo, sem dúvida nenhuma, é cúmplice nesse processo. Isso, porém, não exime o Congresso Nacional de assumir suas responsabilidades. A instituição tem sido palco de sucessivos casos de fisiologismo, nepotismo e busca de vantagens pessoais que golpeiam a confiança da população na própria eficácia da democracia ${ }^{18}$.

Assim, a corrupção de parlamentares e também posturas vistas como antiéticas e não condizentes com a realidade social brasileira (férias prolongadas, semana reduzida de trabalho etc.) por vezes foram interpretadas como motivos da crise, já que agravavam a insatisfação pública, decorrendo daí uma desestabilização da política:

É notório que tem havido um desgaste generalizado da imagem do Parlamento, perante os cidadãos. Na verdade, não podemos dissociar esse desgaste do que também atinge os outros poderes de Estado. Mas não seria este um oportuníssimo momento para melhorar a imagem do Legislativo, se seus próprios integrantes, sponte sua, fizessem passar em suas Casas uma nova lei disciplinadora e moralizadora, no tocante ao próprio trabalho dos legisladores? Será que a redução drástica do período de recesso parlamentar, o cancelamento definitivo de remuneração extra, nos períodos de convocação extraordinária, e a simples introdução do trabalho de segunda a sexta-feira, para os representantes do povo, não significariam um alento ético para um eleitorado dele tão necessitado? ${ }^{19}$

\footnotetext{
18 "Imagem desgastada". FSP, 13/6/2005

19 "Por trás da convocação". OESP, 18/12/2005
} 
MIGUEL, L. F.; COUTINHO, A.A. A crise e suas fronteiras: oito meses de "mensalão"...

(9) Corrupção generalizada, quando os editoriais afirmavam não ser peculiaridade brasileira, nem do governo petista, a prática da corrupção. Antes, esses atos estariam presentes na maioria, senão na totalidade, das democracias modernas. Entre as causas da crise estariam, neste caso, práticas ilícitas encontráveis e conhecidas em toda a parte do globo - a corrupção seria "endêmica nas democracias modernas" 20.

(10) Arcabouço legal, incluindo menções à ineficácia, à obsolescência ou a distorções do ordenamento jurídico, seja eleitoral ou penal (foram bastante comuns expressões que afirmavam que penas suaves não inibem práticas criminosas). Por exemplo, o padrão de financiamento de campanhas era julgado indutor da corrupção - "é a necessidade desse 'custeio eleitoral' que gera, o mais das vezes, as apropriações de recursos públicos, os desvios e as demais irregularidades políticoadministrativas" 21 .

(11) Cultura brasileira não afeita à obediência às leis. Uma suposta cultura brasileira de desrespeito às leis (ou famoso "jeitinho brasileiro") foi algumas vezes citada para explicar os atos de corrupção que levaram à crise: "muito da presente crise se explica pelo hábito de brasileiros em geral e políticos em particular de não levar as leis tão a sério como deveriam"22. Embora essa categoria se refira a um ente abstrato e de longa duração (a cultura), isso não excluiu a possibilidade de responsabilizar o PT pela sua exacerbação, ou melhor, revitalização:

Dos delitos do cotidiano, como entrar em acordo com um profissional liberal para realizar pagamentos sem emissão de nota, aos grandes esquemas de sonegação fiscal ou captura de fundos públicos, estende-se pela sociedade toda uma trama de complacências e licenças que faz da burla - ou do 'jeitinho', em seu pior sentido - quase que um traço nacional.

[...] É óbvio que a corrupção não é uma fenômeno de apenas um país. Aqui, porém, a prática é enraizada e pouco combatida. [...] E a administração petista, que tudo mudaria, vai se revelando apenas uma espécie de versão revista e atualizada do antigo populismo que fez história na região [da América Latina] ${ }^{23}$.

\footnotetext{
20 "Náusea política". FSP, 11/9/2005

21 “O outro 'mensalão'”. OESP, 16/6/2005

22 "Não ao casuísmo". FSP, 18/8/2005

23 "Corrupção enraizada". FSP, 29/8/2005
} 
(12) Falta de governabilidade, isto é, a precariedade de condições do ambiente político em que se devem efetivar as atividades administrativas. As condições materiais do exercício do poder, da legitimidade e da sustentação política do governo fertilizam um ambiente propício à irrupção de crises, como a do "mensalão".

(13) Oportunismo da oposição, acusada, senão de participar dos fatos que levaram propriamente à deflagração da crise, de prolongá-la através de provocações e incitações que apenas aumentavam o desconforto e a desestabilização do cenário político nacional.

(14) Outros motivos, categoria residual que agrupou enquadramentos infreqüentes, correspondendo a $1,5 \%$ do corpus analisado.

Já os "remédios" à crise foram agrupados em 12 categorias:

(1) Investigação minuciosa das denúncias, com o desvendamento completo dos esquemas de corrupção. Mencionou-se, freqüentemente, a importância do Estado Democrático de Direito, cujo um dos princípios estabelece que acusações deve se seguir de provas cabais para legitimar posteriores punições.

(2) Punição dos culpados, mostrando que não caberia impunidade neste caso, o que diminuiria o ceticismo e a instabilidade reinantes na política nacional. Ademais, a punição era vista, também, como prevenção de crises futuras análogas, já que desencorajaria outros atos corruptos.

(3) Reforma política, mudando as leis e criando mecanismos que evitassem e coibissem a corrupção:

Está mais do que comprovado que a atual legislação eleitoral e partidária é o caldo de cultura da corrupção. Como explicou com clareza cristalina o 'professor' Roberto Jefferson, as indicações para cargos de confiança na administração direta e em estatais - hoje mais de 20 mil! - nada mais são do que expedientes para captar 'doações' para os fundos de campanha dos partidos que apóiam o governo. Essa prática contumaz tornou a corrupção um fato corriqueiro na vida política. $O$ mensalão foi apenas o corolário dessa corrupta forma de arrecadação de fundos, consolidada pela proliferação de partidos de aluguel e pelo troca-troca de partidos. A legislação viciada torna o sistema político intrinsecamente corrupto. Enquanto ela vigorar, conselhos de ética, comissões de inquérito e sindicâncias policiais apenas arranharão o verniz que recobre as deformidades da vida políticopartidária. É preciso - e urgente - mudar essa legislação, o que começa a ser feito 
MIGUEL, L. F.; COUTINHO, A.A. A crise e suas fronteiras: oito meses de "mensalão"...

com a aprovação da reforma pela Comissão. O projeto vai agora para o plenário da Câmara e, em seguida, ao Senado. Se aprovado até o final de setembro, vigorará nas eleições de $2006^{24}$.

Uma série de propostas de leis e normas eleitorais passou a ter visibilidade maior, sendo muitas vezes afiançadas como uma forma de se evitar a profusão de atos corruptos como aqueles que deram início à crise estudada. Entre elas estão a chamada "MP do Bem", a aplicação da cláusula de barreira, a pauta legislativa suprapartidária, a adoção de listas fechadas etc.

(4) Evitar crise institucional e a contaminação da economia pela instabilidade política. Como soluções para a crise, ou formas de se evitar seu aprofundamento, foram defendidas, freqüentemente, uma maior imparcialidade do judiciário, uma separação dos poderes constitucionais mais clara e a manutenção da austeridade fiscal, entre outros. Entre as formas de diminuir os efeitos da crise política estava a adequação do campo econômico aos moldes neoliberais.

(5) Desaparelhar a máquina pública e o Estado, significando sobretudo o corte dos cargos de confiança, com a conseqüente "profissionalização" da administração:

O governo Lula faria ainda melhor para recuperar pelo menos em parte da credibilidade que a crise Ihe está corroendo se tivesse coragem de propor medidas que limitassem de maneira drástica o número de cargos a serem preenchidos livremente nas estatais e exigissem de seus ocupantes qualificação técnica. Isso não seria suficiente para eliminar a corrupção, mas reduziria o espaço para seu florescimento ${ }^{25}$.

O presidente Luiz Inácio Lula da Silva poderá proteger a economia brasileira desta e de outras crises políticas se tiver a ousadia de promover duas grandes mudanças: uma ambiciosa reforma do orçamento e uma blindagem de grande parte da administração contra o loteamento de cargos. Com a primeira iniciativa ele conduziria o País a um status mais elevado no sistema econômico e financeiro internacional e consolidaria os fundamentos necessários a um crescimento duradouro. Com a segunda, tornaria mais profissional a gestão do Estado e de suas empresas e tornaria a máquina pública menos vulnerável aos conchavos políticos e à corrupção. Com ambas, tornaria mais arejada e mais democrática a condução dos negócios públicos ${ }^{26}$.

\footnotetext{
24 "A reforma política”. OESP, 26/6/2005

25 "Aproveitar o momento". OESP, 10/6/2005

26 "Momento de ousar". OESP, 21/6/2005 (ênfases acrescentadas)
} 
(6) Evitar o imobilismo do governo, que deveria contestar a ética do Congresso e responder efetivamente, sem subterfúgios, às denúncia. Isso não seria uma solução per se, mas um auxílio inicial e necessário à busca de remédios à crise.

(7) Reforma ministerial, mencionada como necessária para minorar os efeitos da crise, afastando alguns dos principais envolvidos, assim como para dinamizar a política governamental:

Não é admissível que o Planalto, em seu imobilismo, continue a contemporizar com uma situação que se vai mostrando insustentável. É preciso que os suspeitos sejam afastados de seus cargos para responder às acusações e que o presidente conclua a reforma ministerial que vem ensaiando a meses ${ }^{27}$.

(8) Buscar transparência nas contas e atos da administração pública. O amplo acesso às transações financeiras de partidos e do governo aparece como fator fundamental para monitorar o ambiente político e restringir feitos como a compra de votos no Parlamento, o "mensalão".

(9) Evitar casuísmos. Esta categoria abarca todas as críticas da idéia de que a reformulação de leis ou uma reforma política seriam suficientes para solucionar a crise e prevenir outras.

(10) Escolha de nome ilibado para substituir Severino Cavalcanti na presidência da câmara dos deputados.

(11) Reestruturação do PT, com afastamento dos grupos que o comandavam e fim das práticas políticas vistas como nocivas:

Não há dúvida de que a política empreendida pelo grupo de Dirceu foi desastrosa. A esta altura, já ficou claro que a sobrevivência da legenda depende de uma ampla recomposição de seu quadro político-administrativo. Mais que um discurso estéril de vitimização, o PT deve à sociedade sinais de que responderá à crise com uma profunda reformulação interna ${ }^{28}$.

\footnotetext{
27 "O amigo publicitário". FSP, 4/7/2005.

28 "As desculpas do PT". FSP, 18/8/2005
} 
MIGUEL, L. F.; COUTINHO, A.A. A crise e suas fronteiras: oito meses de "mensalão"...

(12) Outros remédios, incluindo propostas mencionadas raramente, alcançando 3,8\% do corpus. O impeachment de Lula, que representaria um desfecho drástico à crise, foi mencionado uma única vez e incluído nesta categoria.

Identificados os enquadramentos presentes nos editoriais e classificados em categorias, tanto na dimensão das "causas" quanto dos "remédios", os dados foram inseridos em software estatístico para que fossem realizados os cruzamentos que alimentam as análises a seguir.

\section{Os editoriais e a crise}

Dos 1803 editoriais publicados no período sob análise, 26,2\% tratavam da crise do "mensalão", o que a torna a categoria temática mais freqüente. Seguem-se economia brasileira (15\%) e internacional (11,4\%); juntas, as três categorias somam mais da metade do corpus de análise. Para qualquer um dos três jornais, a crise foi o tema mais presente, com percentuais bastante próximos, ao passo que outras categorias demonstram maior disparidade (Tabela 1).

Cumpre observar que o volume total de editoriais variou ou muito entre os três jornais. Nos oito meses sob a análise, O Estado de S. Paulo publicou 735 editoriais, enquanto a Folha de S. Paulo publicou 680 e O Globo, apenas 388. Esta disparidade se refletiu também nos textos sobre a crise, dos quais $40,7 \%$ são do Estado, 35,6\% da Folha e 23,7\% do Globo.

Tabela 1: Temáticas mais presentes nos editoriais do jornais, maio/dezembro de 2005

\begin{tabular}{l|c|c|c|c}
\hline & Folha & Estado & Globo & total \\
\hline Crise política & $24,7 \%$ & $26,1 \%$ & $28,9 \%$ & $26,2 \%$ \\
\hline Economia brasileira & $18,5 \%$ & $12,1 \%$ & $14,2 \%$ & $15 \%$ \\
\hline Internacional & $15,6 \%$ & $7,5 \%$ & $14,9 \%$ & $12,1 \%$ \\
\hline Ações do poder executivo & $7,1 \%$ & $10,9 \%$ & $2,6 \%$ & $7,7 \%$ \\
\hline Relações exteriores & $2,9 \%$ & $10,3 \%$ & $3,9 \%$ & $6,2 \%$ \\
\hline Cidades/Brasil & $4,7 \%$ & $4,8 \%$ & $5,9 \%$ & $5 \%$ \\
\hline
\end{tabular}

Fonte: os autores.

Deflagrada em maio, a crise dominou os editoriais nos quatro meses seguintes, quando foi tratada em mais de $30 \%$ deles, com picos em julho $(37,9 \%$ dos editoriais falam da crise) e agosto (38,3\%). A partir daí, entrou em declínio, 
respondendo por apenas $17 \%$ dos editoriais em dezembro, o que ilustra o fenômeno do "ciclo de atenção da mídia"29. O prolongamento da pesquisa pelo primeiro semestre de 2006 talvez mostrasse uma nova onda de atenção ao tema, sobretudo com as denúncias que atingiram o ministro da Fazenda, Antônio Palocci, levando à sua renúncia em março.

Nestes 472 editoriais que tratavam da crise, as personagens mais freqüentes foram o Partido dos Trabalhadores (em 68,6\% deles), o presidente da República (em 59,5\%) e o governo da União (em 50,2\%). O foco no PT, como organização partidária, mais do que em seus líderes ou na administração federal, já indica que a denúncia das "promessas vãs" do petismo - que faria política de um jeito diferente, que seria guardião da ética - foi um dos elementos centrais do enquadramento da crise. Os partidos seguintes mais lembrados, PSDB e PTB, apareceram, cada um, em $11,7 \%$ dos editoriais sobre a crise.

Ao todo, foram citados quase 400 nomes, entre indivíduos e organizações, dos quais mais de 300 foram lembrados em menos de 10 editoriais. O dado demonstra a pulverização do foco quanto aos atores secundários, fato que se explica em parte pela própria constituição da crise: um encadeamento de vários escândalos surgidos ao longo do tempo envolvendo personagens das mais diversas.

Gráfico 1: Personagens citadas em 100 ou mais editoriais de jornais sobre a crise, maio/dezembro de 2005

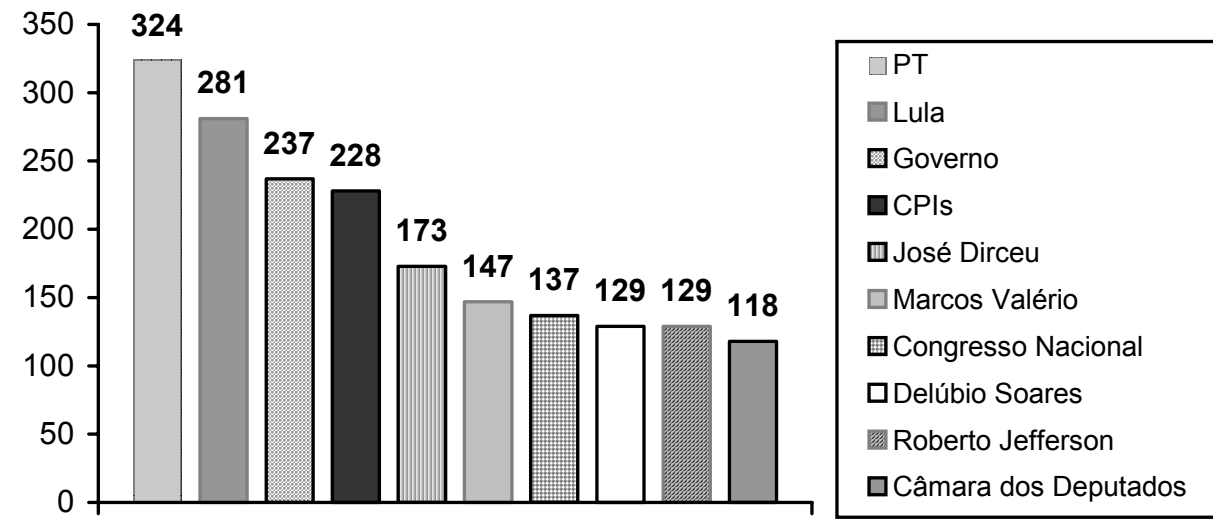

Fonte: os autores

${ }^{29}$ A expressão foi celebrizada por Downs (1972). 
MIGUEL, L. F.; COUTINHO, A.A. A crise e suas fronteiras: oito meses de "mensalão"...

Algumas das personagens mais citadas apareceram de forma relativamente constante ao longo do tempo, caso do PT, de Lula e do governo - todos apareceram um pouco menos em setembro, mês em que Severino Cavalcanti foi um dos grandes protagonistas dos editoriais, e em novembro Lula esteve mais presente e o governo, menos, mas, no geral, as alterações forem pouco significativas. Já a aparição de Marcos Valério teve seu pico em julho e agosto e Roberto Jefferson declinou acentuadamente a partir de setembro, quando de sua cassação, o que os identifica claramente como desempenhando papéis estrepitosos, mas secundários, no desenrolar da crise.

Entre os motivos da crise, destaca-se, com nitidez, a corrupção. Nada menos que $95,3 \%$ dos editoriais que trataram do tema mencionaram ao menos uma das categorias focadas na corrupção, sobretudo a corrupção do PT e seus líderes (57,2\%) e a corrupção da administração petista (54\%), que foram, de longe, os motivos mais citados para a crise - em terceiro lugar, apareceram denúncias inespecíficas de corrupção, com 16,9\%. Os números revelam, que uma boa parcela dos editoriais indicava mais de um elemento de corrupção como causa da crise.

Na linha do tempo, destacou-se o declínio do "fisiologismo" como causa indicado em $38,1 \%$ dos editoriais que abordaram o tema em maio, apareceu em apenas 2,6\% em dezembro. Ao que parece, as evidências surgidas ao longo do processo fortaleceram a idéia de que, para além da mera transgressão moral (caracterizada pelo "fisiologismo"), houve a violação de regras legais. Cresceu, ao contrário, a referência à corrupção à corrupção do PT e de seus líderes, presente em menos de $40 \%$ dos editoriais sobre a crise em maio e junho, mas superando os $60 \%$ em cinco dos outros seis meses estudados.

Das categorias apresentadas na seção anterior, três culpabilizavam expressamente o PT, Lula ou o governo federal - além de "corrupção do PT e/ou de seus líderes" e "corrupção da administração petista", há "inexperiência de Lula e/ou do PT para governar". Uma grande maioria dos editoriais incluiu ao menos uma destas categorias, revelando a percepção de que o presidente, seu partido e seu governo foram os principais responsáveis pela eclosão da crise política (Gráfico 2). 
Gráfico 2: Responsabilização do PT, de Lula e/ou do governo nos editoriais de jornais sobre a crise, maio/dezembro de 2005

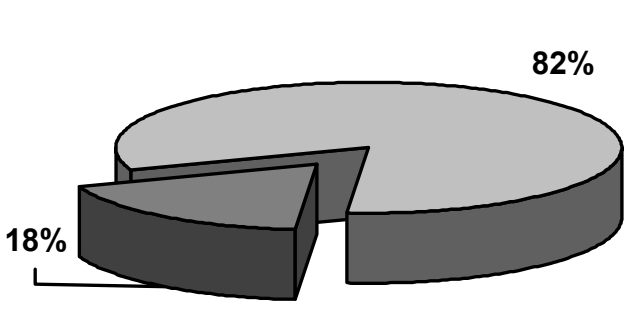

$\square$ Incluem elementos de responsabilização do PT, de Lula e/ou do governo

Não incluem elementos de responsabilização do $\mathrm{PT}$, de Lula e/ou do governo

$n=472$

Fonte: os autores

Ainda mais significativo foi o agrupamento dos motivos da crise em dois grandes grupos. De um lado, o que chamamos aqui de "causas personalistas", em que a explicação para o surgimento da crise é dada pelas ações ou omissões de um agente ou grupo de agentes, incluídos aí tanto pessoas quanto instituições. Do outro, "causas abstratas", que deslocam o foco para motivos históricos, culturais ou estruturais, vinculados à organização política do país ou a comportamentos enraizados das elites ou do povo brasileiro.

No primeiro grupo, estão "Corrupção do PT e/ou de seus líderes", "Corrupção da administração petista", "Denúncias de corrupção inespecíficas", "Inexperiência de Lula e/ou do PT para governar", "Severino Cavalcanti e o “mensalinho”, "Corrupção do Legislativo", "Oportunismo da Oposição" e "Aparelhamento da máquina pública/Estado". Esta última categoria poderia se referir a um fenômeno de mais longo curso, mas nos editoriais apareceu, na quase totalidade dos casos, como a denúncia das práticas da administração presente. Já sob o rótulo de "Causas abstratas" foram agrupados "Corrupção generalizada", "Arcabouço legal", "Cultura brasileira não afeita à obediência às leis" e "Falta de governabilidade".

A ampla presença de "causas personalistas" não causa estranheza, uma vez que mesmo razões históricas e estruturais, de longa duração, só se manifestam incorporadas nas ações de agentes concretos. O que chama a atenção é a quase ausência das "causas abstratas", incluídas em apenas 7,2\% dos editoriais, conforme mostra o gráfico 3. A parcela dos textos que aborda exclusivamente causas abstratas não alcança sequer $1 \%$ do corpus.

Trata-se, conforme observou Gamson, de um fenômeno próprio à forma narrativa da notícia, que "tende a concretizar alvos" e "freqüentamente apresenta razões para as pessoas se zangarem com alguém. Obviamente, esse 'alguém' não precisa ser a verdadeira fonte de todo sofrimento, mas apenas um substituto 
MIGUEL, L. F.; COUTINHO, A.A. A crise e suas fronteiras: oito meses de "mensalão"...

conveniente" (GAMSON, 1992, p. 34). No caso dos editoriais, que não estão presos às convenções narrativas do texto noticioso, é mais razoável falar em uma opção de caráter ideológico.

\section{Gráfico 3: Tipos de causas da crise nos editoriais de jornais, maio/dezembro de 2005}

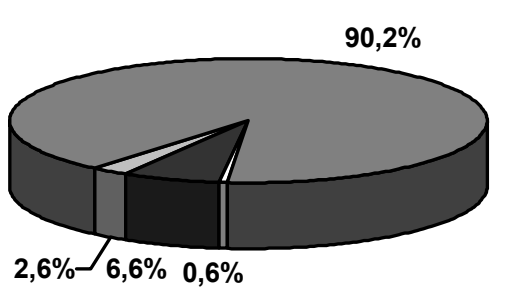

$\square$ Causas personalistas $\square$ Causas abstratas

$n=472$

Fonte: os autores

Alguns excertos ilustram com clareza a personalização da crise levada a cabo pelos editoriais:

Até terça-feira passada, o sinônimo da crise era Luiz Inácio Lula da Silva, cujas omissões tornaram-no o 'grande culpado' dos problemas de seu governo, como se comentou neste espaço. Naquele dia, por ações e palavras, ele fez o que deveria ter feito desde a primeira hora, colocando-se a anos-luz de distância do presidente que, diante do recém-revelado escândalo dos Correios, alardeou bisonhamente seu alheamento. 'Olha para minha cara para ver se eu estou preocupado', disse então a um repórter, para demonstrar o seu estado de espírito zen. Mas se Lula, enfim, resolveu segurar com mão firme o leme de um governo ameaçado de adernar em meio à mais inclemente tormenta que sobre ele se abateu nesses seus dois anos e meio de existência, a crise no Planalto parece a caminho de assumir um novo nome: José Dirceu de Oliveira e Silva ${ }^{30}$

Ao enunciar [os governistas] uma prática que seria generalizada, a argumentação tenta afastar a necessária responsabilização individual e transferir o problema para uma solução sistêmica. Então, passa a pregar a necessidade de reformar as regras político-eleitorais, que seriam as culpadas em última instância por tudo o que está acontecendo. Esse exercício retórico, porém, não resiste à lógica ${ }^{31}$.

\footnotetext{
30 "O novo nome da crise". OESP, 11/6/2005 (ênfases acrescentadas)

31 "Caixa dois não anistia". FSP, 16/10/2005.
} 
Embora em linhas gerais se mostrassem bastante similares, as abordagens dos três jornais apresentaram algumas diferenças significativas. Em O Estado de $S$. Paulo, a corrupção foi focada no PT e em seus dirigentes, mais do que na administração federal, ao contrário do que ocorreu nos outros dois jornais. Também no Estado, a inexperiência do presidente e de seu partido aparece como motivo importante para a crise - foi o terceiro mais citado no jornal, presente em quase um quarto dos editoriais que enfocaram o tema -, o que não se verificou na Folha ou no Globo. O diário carioca, por sua vez, foi o único a dar ênfase ao aparelhamento da máquina pública. Chamou a atenção, ainda, o fato de que $O$ Estado de $S$. Paulo não mencionou nem uma única vez o "oportunismo da oposição" como motivo para a crise. Pelo contrário, foi capaz de exaltar o "comportamento exemplar da oposição", responsável por evitar "a transformação da crise política em institucional"32.

De forma geral, a tabela 2 indica um anti-petismo e anti-lulismo mais acentuados no Estado do que nos outros jornais. O Globo, por sua vez, mostrou-se como o mais moderado.

Tabela 2: Causas da crise nos editoriais que trataram do tema, maio/dezembro de 2005

\begin{tabular}{l|c|c|c|c}
\hline & Folha & Estado & Globo & total \\
\hline Corrupção do PT e/ou de seus líderes & $56 \%$ & $62,5 \%$ & $50 \%$ & $57,2 \%$ \\
\hline Corrupção da administração petista & $56,5 \%$ & $51,6 \%$ & $54,5 \%$ & $54,0 \%$ \\
\hline Denúncias de corrupção inespecíficas & $20,2 \%$ & $16,1 \%$ & $13,4 \%$ & $16,9 \%$ \\
\hline Fisiologismo & $12,5 \%$ & $18,2 \%$ & $15,2 \%$ & $15,5 \%$ \\
\hline Inexperiência de Lula e/ou do PT para governar & $8,3 \%$ & $23,4 \%$ & $6,3 \%$ & $14,0 \%$ \\
\hline Aparelhamento da máquina pública/Estado & $1,2 \%$ & $8,9 \%$ & $26,8 \%$ & $10,4 \%$ \\
\hline Eleição de Severino Cavalcanti & $6 \%$ & $5,2 \%$ & $5,4 \%$ & $5,5 \%$ \\
\hline Corrupção do Legislativo & $4,2 \%$ & $3,6 \%$ & $1,8 \%$ & $3,4 \%$ \\
\hline Corrupção generalizada & $3,0 \%$ & $1,6 \%$ & $3,6 \%$ & $2,5 \%$ \\
\hline Arcabouço legal & $\cdot$ & $1 \%$ & $7,1 \%$ & $2,1 \%$ \\
\hline Cultura brasileira não afeita à obediência às leis & $3,6 \%$ & $\cdot$ & $1,8 \%$ & $1,7 \%$ \\
\hline Falta de governabilidade & $0,6 \%$ & $1,6 \%$ & $2,7 \%$ & $1,5 \%$ \\
\hline Oportunismo da oposição & $1,2 \%$ & $\cdot$ & $3,6 \%$ & $1,3 \%$ \\
\hline outros & $\cdot$ & $1 \%$ & $4,5 \%$ & $1,5 \%$ \\
\hline nenhum & $3,6 \%$ & $1 \%$ & $2,7 \%$ & $2,3 \%$ \\
\hline
\end{tabular}

Fonte: os autores

32 "O grande culpado". OESP, 8/6/2005. 
MIGUEL, L. F.; COUTINHO, A.A. A crise e suas fronteiras: oito meses de "mensalão"...

Entre os remédios propostos, destacaram-se a investigação das denúncias e a punição dos culpados por corrupção, o que é congruente com o foco em causas personalistas para a crise. Como explica Gamson, "se a indignação moral é estimulada pela indicação dos 'caras maus' [bad guys], ela é rápida e facilmente diminuída pela remoção deles" (GAMSON, 1992, p. 35). Como mostra o gráfico 4, quaisquer outros remédios apresentados se situam em posição francamente minoritária em relação a estes dois. Uma grande parcela de editoriais (110, isto é, $23,3 \%$ ), por outro lado, se absteve de apresentar qualquer proposta para debelar a crise.

Entre os 362 editoriais que apresentaram algum remédio à crise, 92\% incluíam mecanismos focado no combate à corrupção; apenas 18,5\% mencionaram soluções que privilegiavam outros aspectos. Por todos os dados aqui apresentados, fica evidente que a crise, de acordo com a opinião dos jornais, foi uma crise de corrupção.

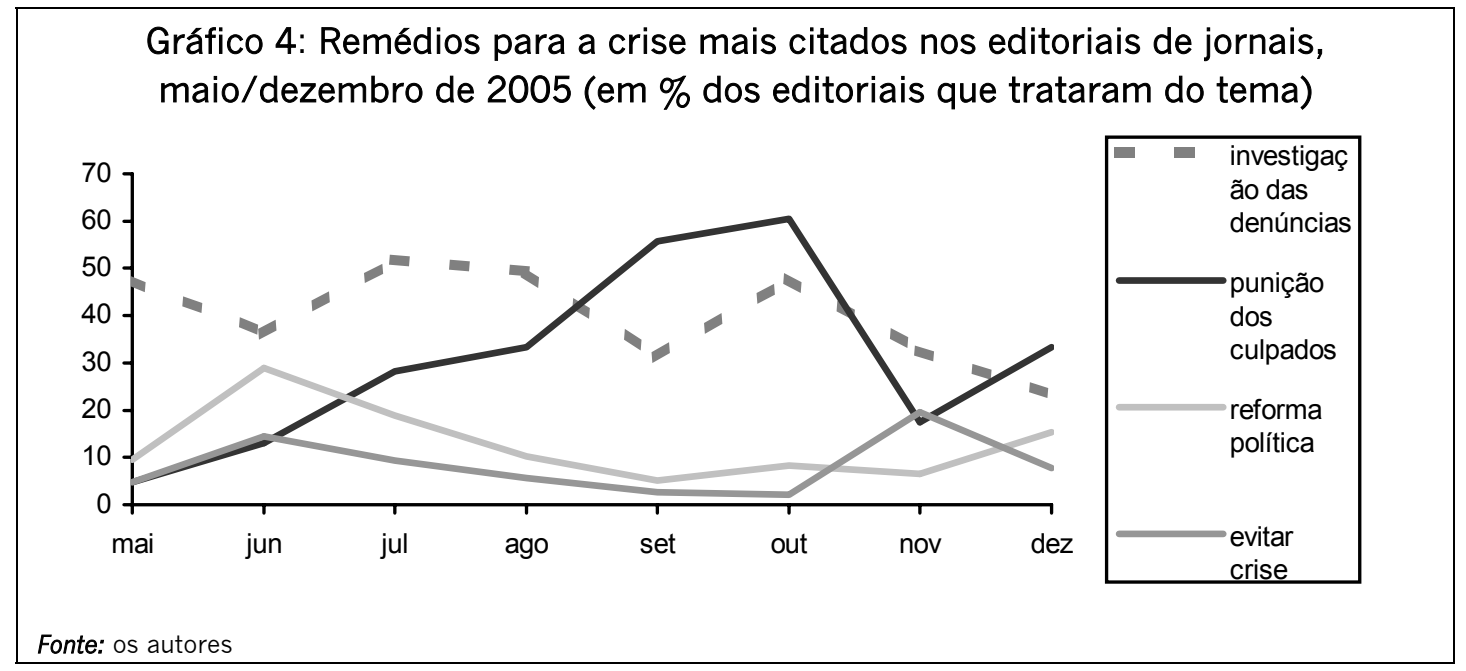

O aspecto senoidal da linha vinculada à investigação das denúncias, no gráfico 4, se explica pela dinâmica da crise, em que diversos escândalos se encadeavam. Cada nova denúncia ensejava a exigência de sua confirmação, isto é, uma averiguação cuidadosa dos fatos. Corroborada a sua veracidade, tornava-se necessário punir os culpados, categoria que cresceu mês a mês até outubro. A queda brusca no mês de novembro está associada ao crescimento da categoria "evitar crise institucional". Pela primeira vez, o escândalo chegou ao então ministro da Fazenda, Antônio Palocci. Punir eventuais culpados tornava-se medida 
secundária diante da necessidade de evitar a descontinuidade da política econômica, da qual Palocci era considerado o principal fiador.

Entre os três jornais, mais uma vez, é possível detectar semelhanças no atacado, a começar pela preponderância das categorias vinculadas à investigação das denúncias e à punição dos culpados, mas com algumas diferenças importantes, apresentadas da tabela 3. Muito mais do que os diários paulistas, O Globo destacou a importância da reforma política, presente em quase um terço dos seus editoriais sobre o tema. A Folha de S. Paulo, por sua vez, se singularizou pela menor preocupação com evitar a crise institucional, presente em 4,2\% dos seus editoriais, contra mais de $10 \%$ nos outros dois jornais, e com o desaparelhamento da máquina pública, que não citou sequer uma vez.

Tabela 3: Remédios à crise nos editoriais que trataram do tema, maio/dezembro de 2005

\begin{tabular}{l|c|c|c|c}
\hline & Folha & Estado & Globo & total \\
\hline Investigação minuciosa das denúncias & $39,9 \%$ & $41,7 \%$ & $41,1 \%$ & $40,9 \%$ \\
\hline Punição dos culpados por corrupção & $29,2 \%$ & $31,8 \%$ & $41,1 \%$ & $33,1 \%$ \\
\hline Reforma política & $8,3 \%$ & $7,8 \%$ & $31,3 \%$ & $13,6 \%$ \\
\hline Evitar crise institucional & $4,2 \%$ & $10,4 \%$ & $10,7 \%$ & $8,3 \%$ \\
\hline Desaparelhar a máquina pública/Estado & - & $8,9 \%$ & $10,7 \%$ & $6,1 \%$ \\
\hline Evitar imobilismo do Governo & $2,4 \%$ & $2,6 \%$ & $9,8 \%$ & $4,2 \%$ \\
\hline Reforma ministerial & $3,0 \%$ & $3,1 \%$ & $4,5 \%$ & $3,4 \%$ \\
\hline $\begin{array}{l}\text { Buscar transparência na administração } \\
\text { pública }\end{array}$ & $6,5 \%$ & $1,0 \%$ & $1,8 \%$ & $3,2 \%$ \\
\hline Evitar casuísmos & $3,0 \%$ &. & $6,3 \%$ & $2,5 \%$ \\
\hline Escolha de nome ilibado para substituir & $3,6 \%$ & $1,0 \%$ & $1,8 \%$ & $2,1 \%$ \\
Severino Cavalcanti & & & & \\
\hline Reestruturação do PT & $1,2 \%$ & $2,1 \%$ & $1,8 \%$ & $1,7 \%$ \\
\hline outros & $4,2 \%$ & $2,6 \%$ & $5,4 \%$ & $3,8 \%$ \\
\hline nenhum & $28,6 \%$ & $26,6 \%$ & $9,8 \%$ & $23,3 \%$ \\
\hline
\end{tabular}

Fonte: os autores

Proporcionalmente, $O$ Globo apresentou mais remédios à crise do que os jornais de São Paulo - foram, em média, 1,66 propostas em cada editorial sobre a crise, contra 1,13 de O Estado de S. Paulo e 1,05 da Folha de S. Paulo. Isto contribuiu para que apresentasse um elenco mais diversificado, em que, além das duas categorias comuns a todos os veículos, outras ganharam importância. A maior 
MIGUEL, L. F.; COUTINHO, A.A. A crise e suas fronteiras: oito meses de "mensalão"...

presença de editoriais que sugeriam "evitar crise institucional" e "evitar imobilismo do governo" - isto é, medidas que visam garantir a continuidade da ação governamental -, por sua vez, sinalizava para uma posição mais cautelosa no enfrentamento com Lula. Uma explicação possível para a divergência está no fato de que as Organizações Globo, um conglomerado muito maior e mais influente do que as empresas controladoras do Estado e da Folha, mantinham relação privilegiada com o governo, com ligação íntima com o ministro das Comunicações (nomeado em meio à crise, em agosto de 2005), seu ex-funcionário Hélio Costa, e interessadas diretas numa decisão crucial que estava sendo tomada no período, o padrão da televisão digital brasileira.

\section{Conclusões}

A cobertura da crise do mensalão pelos três jornais em foco, assim como pelo restante da mídia, ao longo de 2005 e também em 2006, foi "dura". Ainda que falte uma análise mais aprofundada do noticiário, a unanimidade dos observadores chega a esta conclusão. O núcleo de poder do governo federal foi atingido em ondas sucessivas. Em 16 de junho de 2005, o ministro-chefe da Casa Civil, José Dirceu, tido como homem forte do governo, renunciou ao cargo (e teria seu mandato de deputado federal cassado meses depois). Em 27 de março de 2006, o governo Lula perderia seu outro homem forte, o ministro da Fazenda, Antônio Palocci, em conseqüência de um dos desdobramentos do escândalo.

Os editoriais aqui analisados revelam essa severidade. Mesmo O Globo merece o qualificativo de "moderado" apenas em contraposição aos diários paulistas. Em mais da metade dos editoriais de qualquer um dos três veículos, o presidente da República, seu governo ou seu partido foram acusados de corrupção.

No entanto, quando analisavam os motivos da crise ou propunham alternativas para sua superação, os editoriais se mantiveram dentro da lógica da ordem vigente. De fato, a natureza do escândalo, associada à perda das esperanças com uma gestão governamental "diferente" - que Lula e o Partido dos Trabalhadores representavam -, abria as portas à possibilidade de uma negação radical da política concorrencial estabelecida, na linha do que se vayan todos argentino de 2001, que postulava a remoção de toda a elite política e apontava na direção de novas, ainda que obscuras, formas de organização social. Para além da improbidade deste ou daquele administrador público, o episódio punha a nu a baixa capacidade de controle dos representantes por seus constituintes, bem como o inevitável extravasamento das desigualdades materiais para a arena política.

Para os três jornais, a crise política resultou do descumprimento de regras legais (corrupção) ou de normas morais tácitas (fisiologismo) que deveriam reger o 
comportamento político. A solução estaria no cumprimento da lei (investigação e punição dos culpados), secundada por modificações acessórias nas regras em vigor (mudança do sistema eleitoral, redução dos cargos de confiança). Apesar das diferenças de ênfase, este retrato vale para qualquer dos diários analisados.

Mesmo quando eram apontados defeitos na democracia concorrencial estabelecida, as alternativas para remediá-los não extrapolavam a mera revisão de algumas normas legais:

As dimensões da crise são amplas. Ela expõe as graves distorções do sistema político brasileiro e as deficiências da representatividade parlamentar na nossa democracia. Também desnuda as doenças de um Estado obeso e que mantém indecentes e incestuosas relações com esse mundo político, cujo funcionamento tem sido regido por usos e costumes à margem de qualquer padrão ético aceitável. [...]

Luiz Inácio Lula da Silva e a classe política têm o desafio estratégico de assumir agora uma agenda que retome a reforma do Estado - abandonada nesse governo - e inclua a modernização das instituições políticas e de representatividade do cidadão, pela revisão das normas que regem a vida parlamentar e dos partidos"33.

Tratava-se, portanto, de uma questão de "deficiências" a serem sanadas pela redução do Estado e pela "modernização" das regras políticas. Não houve, nem mesmo nas raras ocasiões em que foram apontadas causas estruturais para a crise, qualquer espaço para uma discussão sobre o afastamento entre as instituições representativas e o povo que é titular nominal da soberania, afastamento que não é contingente, mas que é próprio das democracias eleitorais. Muito menos para pôr em questão a relação entre a economia capitalista, marcada pela desigualdade de recursos entre os agentes privados, e a esfera política formalmente democrática, em que todos têm condições pretensamente iguais de influência. No entanto, desde seu início, o escândalo ilustrou o transbordamento da desigualdade econômica para a arena política.

Tal transbordamento não é a exceção, mas a regra. No mundo dos editoriais de O Estado de S. Paulo, Folha de S. Paulo e O Globo, porém, percebe-se o inverso. A crise foi marcada pelo signo do desvio. Indivíduos nefandos burlam as regras, que precisam ser respeitadas ou, quando muito, reforçadas de maneira a impedir que os malfeitores tenham sucesso. Com a punição dos maus e as devidas medidas

\footnotetext{
33 "Agenda de choque". OG, 8/6/2005 (ênfases acrescentadas).
} 
MIGUEL, L. F.; COUTINHO, A.A. A crise e suas fronteiras: oito meses de "mensalão"...

profiláticas para evitar que episódios similares ocorram, volta-se à "normalidade", isto é, ao adequado funcionamento do sistema.

A análise dos editoriais indica que os meios de comunicação podem ter sido "incendiários" na conjuntura, mas adotaram antes a postura de "bombeiros" em relação a possíveis questionamentos de longo alcance do sistema político e de sua relação com o sistema econômico. O "ideal político" que suas representações forjam é inequivocamente conservador.

Daniel Hallin afirmou, em estudo hoje clássico, que a imprensa, quando se abre para o contraditório, se movimenta dentro de um espaço de "controvérsia legítima" (HALLIN, 1986, p. 116-7). Posições que vão além deste espaço são silenciadas. No caso do mensalão, as fronteiras da legitimidade foram dadas pela permanência das características centrais do regime de democracia concorrencial limitada sob economia capitalista. Em suma, nas categorias de lyengar, ainda que o jornalismo possa adotar uma postura "opositiva" quanto ao governo - como ocorreu, em alguns veículos de forma agressiva, na gestão de Lula -, ele permanece "deferente" ao sistema político e suas principais instituições (IYENGAR, 1991). Colabora, assim, para estabelecer o fato de que política é isso, política se faz assim, e que é possível pensar em reformá-la, mas não em fugir da lógica já dada. 


\section{Referências bibliográficas}

ABREU, A. A. e LATTMAN-WELTMAN, F. Controles midiáticos: investigação e denuncismo na construção da visibilidade pública democrática. In: XXV Encontro Anual da ANPOCS, 2001, Caxambu.

CAPPELA, J. N. e K. H. J. Spiral of cinicism: the press and the public good. Oxford: Oxford University Press, 1997.

DOWNS, A. Up and down with ecology: the "issue-attention cycle". The Public Interest, Washington, $\mathrm{n}^{\circ} 28$, p. 38-50, 1972.

GAMSON, W. Talking politics. Cambridge : Cambridge University Press, 1992.

HALLIN, D. The "uncensored" war: the media and Vietnam. Berkeley: University of California Press, 1986.

IYENGAR, S. Is anyone responsible? How television frames political issues. Chicago: The University of Chicago Press, 1991.

LATTMAN-WELTMAN, F. Mídia e poliarquia: denuncismo e oligarquia. In: XI Encontro da COMPÓS, 2002, Rio de Janeiro.

LIMA, V. A. Presunção de culpa: a cobertura da crise política de 2005-2006. In: Mídia: crise política e poder no Brasil. São Paulo, Fundação Perseu Abramo, 2006.

MACHADO, C. A. M. Identidades diluídas: consistência partidária das coligações para prefeito no Brasil. Dissertação de Mestrado em Ciência Política. Brasília, Universidade de Brasília, 2007.

MARINI, A. R. Com quantas manchetes se derruba um presidente? Mídia e Democracia, São Paulo, n 5, p. 16-22, 2007.

MIGUEL, L. F. From equality to opportunity: transformations in the discourse of Workers' Party in the 2002 elections. Latin American Perspectives, Riverside, vol. 33, n 4, p. 122.43, 2006.

PRZEWORSKI, A. Capitalism and social democracy. Cambridge: Cambridge University Press, 1985. 
RIBEIRO, P. J. F. O PT sob uma perspectiva sartoriana: de partido anti-sistema a legitimador do sistema. Política \& Sociedade, Florianópolis, n³ 3, p. 45-70, 2003.

RUBIM, A. A. C. Cultura e política na eleição de 2002: as estratégias de Lula presidente. En: XII Encontro da COMPÓS, 2003, Recife.

THOMPSON, J. B. O escândalo político. Petrópolis: Vozes, 2002. 